DOI: $10.33067 /$ SE.1.2021.2

Dimitry Vladimirovich Kochenov ${ }^{\star}$

\title{
Policing the Genuine Purity of Blood: The EU Commission's Assault on Citizenship and Residence by Investment and the Future of Citizenship in the European Union
}

\begin{abstract}
This article provides a brief critical assessment of the European Commission's January 2019 "Report on Investor Citizenship and Residence Schemes in the European Union". Since it is the first detailed document by the Commission outlining this institution's position on the matters of investment residence and citizenship, and given the Commission's recently articulated intentions to take Cyprus and Malta to Court over their investment migration law and practice, the Report in question is of paramount importance. The document sets the legal-political context of the regulation of the migration of wealthy third-country nationals in Europe. It is also deeply flawed. Rather that summarising the document, this article focuses on five core deficiencies of the Commission's embarrassing product and demonstrates how the Commission failed to get the EU's own law right, in addition to showing a poor understanding of international law on the matter. Ripe with nationalist assumptions not rooted in the Treaties or the secondary law of the Union and showcasing a timid, convoluted and inconsistent analysis of the issues it purports to address, the Report has unsurprisingly failed to change the landscape of regulation in the field of investment citizenship and residence in the EU or anywhere else in the world. What it did make clear, however, was that the mere political
\end{abstract}

* Dimitry Vladimirovich Kochenov - Fellow, COMPAS, University of Oxford; Senior Research Fellow, CEU Democracy Institute, Budapest; Professor, CEU Department of Legal Studies, Vienna, e-mail: kochenovd@ceu.edu, ORCID: 00000001-9266-1188. 
suspicion of a particular type of naturalisation is enough for the European Commission to set aside the law and misinform the public, underlying once again the problematic tension between the growing political nature of this institution and its key task as guardian of the Treaties. There is a burning need for the Commission to take a more careful, coherent and informed approach to its actions, an approach indispensable for the preservation of the rule of law in the Union.

Keywords: CBI, RBI, Investment Migration, Citizenship by Investment, Rule of Law

\section{Introduction: Citizenship Law and the Moral Panics of Innate "Native" Superiority}

Not only are the refugees and asylum seekers "flooding Europe" routinely demonised and subjected to intense prejudices. ${ }^{1}$ Millionaires can also be a problem for "Fortress Europe", especially if they "buy" the sacred privileges of Europeanness, instead of winning them in the "birthright lottery" or "earning" them by humbly waiting and enduring routine humiliation like all the other 'others' whom the European Union (EU) is carefully calibrated to keep at bay. ${ }^{3}$ Being vocal about the absoluteness of 'native' superiority can be extremely costly, however, as the marketisation of citizenship and residence can bring billions of euros to the Member States' crisis-stricken budgets. ${ }^{4}$ This dilemma lies at the core of the ongoing debate surrounding the phenomenon of investment migration in

${ }^{1}$ On the attitudes to refugees in Europe, see e.g. K. Bansak, J. Hainmueller and D. Hangartner, How Economic, Humanitarian, and Religious Concerns Shape European Attitudes toward Asylum Seekers, "Science”, no. 354 (6309)/2016, p. 217.

2 A. Shachar, The Birthright Lottery, Cambridge MA 2009.

3 On the problematic ideology of "integration", see e.g. S. Ganty, Lintégration des citoyens européens et des ressortissants de pays tiers en droit de l'Union européenne. Critique d'une intégration choisie, Paris 2021. It is worth keeping in mind that the EU is the only advanced constitutional system in the world, where third country nationals are not entitled to benefit from any of the core rights offered to citizens, including, especially, being part of the EU's internal market. EU law is thus the only law in the world elevating nationality discrimination to the absolute: without the 'right' nationality the EU disappears as a territory and as a horizon of opportunities: D. Kochenov, M. van den Brink, Pretending There Is No Union: Non-Derivative Quasi-Citizenship Rights of Third-Country Nationals in the EU, in: Degrees of Free Movement and Citizenship, eds. D. Thym, M. Zoetewij-Turhan, Leiden 2015, p. 66.

4 J. Lindeboom, S. Meunier, Foreign Direct Investment and Investment Migration Programmes in the European Union, in: Citizenship and Residence Sales: Rethinking the Boundaries of Belonging, eds. D. Kochenov, K. Surak, Cambridge 2021 (forthcoming). 
Europe. ${ }^{5}$ In this article I focus precisely on this dilemma and the moral panic it provokes: if EU citizenship is sacred and rooted in the native possession of pure European blood providing a "genuine link" to Europe, how come someone can buy it, thus foregoing the necessary humiliation of ordinary naturalization? As we will see, the European Commission had a lot to say on this matter in its 2019 "Report on Investment Citizenship and Residence Schemes in the European Union" - and proved willing to sacrifice the free movement of persons in the internal market and the basic principles flowing from the key Court of Justice of the European Union (ECJ) case law in this area, on the altar of the obscurantist nativism that the EU was precisely designed to destroy by outlawing discrimination on the basis of nationality. ${ }^{7}$ In outlining five core flaws of the Commission's Report, this article is in full agreement with Ulli Jessurun d'Oliveira's analysis: ${ }^{8}$ Member State competence on the matter of granting citizenship reigns supreme unless they start deploying nationalist ideologies of citizenship in order to humiliate Europeans and deprive them of rights related to the citizenship status, which are provided by EU law. Moreover, as Martijn van den Brink has convincingly argued, EU law cannot be deployed to enforce any "genuine link" requirements ${ }^{9}$ - that without defeating the purpose of EU citizenship, as will be analysed also below. Consequently, the Commission needs to be more humble to do less harm in this fundamentally important field. What we can observe, however, is the exact opposite of humbleness, as the Commission deployed the flawed reasoning of its 2019 Report dissected below as a base for a direct action against Cyprus and Malta, communicated on 20 October 2020. ${ }^{10}$

5 For an in-depth analysis, see: Citizenship and Residence Sales: Rethinking the Boundaries of Belonging, eds. D. Kochenov, K. Surak, Cambridge 2021 (forthcoming).

6 European Commission, Report from the Commission to the European Parliament, the Council, the European Economic and Social Committee of the Regions $\operatorname{COM}(2019) 12$ final. Cf. Questions and Answers on the Report on Investor Citizenship and Residence Schemes in the European Union, https://europa.eu/rapid/pressrelease_MEMO-19-527_en.htm (access 1.08.2020).

7 W. Maas, Creating European Citizens, Boston 2007; G. Davies, Nationality Discrimination in the Internal Market, The Hague 2003. Cf. J.H.H. Weiler, Europe: The Case against the Case of Statehood, "European Law Journal”, no. 4/1998, p. 61.

${ }^{8}$ H.U. Jessurun d'Oliveira, Union Citizenship and beyond, in: European Citizenship under Stress: Social Fustice, Brexit, and Other Challenges, eds. N. Cambien, D. Kochenov, E. Muir, Boston 2020.

9 M. van den Brink, Revising Citizenship within the European Union: Is a Genuine Link Requirement the Way Forward?, "EUI Working Papers” RSCAS, no. 76/2020, p. 17.

${ }^{10}$ European Commission (press release), Investor Citizenship Schemes: European Commission Opens Infringements against Cyprus and Malta for "Selling" EU Citizenship, Brussels, 20 Oct. 2020, https://ec.europa.eu/commission/presscorner/detail/ 
Alongside the UK with its Tier 1 visa, ${ }^{11}$ the US with its EB- $-5^{12}$ and formerly Canada, ${ }^{13}$ the EU is among the world leaders in investment migration, ${ }^{14}$ reaping the benefits of the desire of wealthy people around the world either to establish themselves in the EU, or to acquire EU citizenship, which is of much higher quality than the majority of world nationalities. ${ }^{15}$ Every year a handful of billionaires and thousands of millionaires acquire citizenship and residence through investment or donation on both sides of the Atlantic. ${ }^{16} \mathrm{~A}$ whole industry has emerged around this, as it has around other areas of migration and modes of citizenship acquisition. ${ }^{17} \mathrm{~A}$ small but opinionated body of moral panic literature has also mushroomed around the issues of whether citizenship - a randomly

en/ip_20_1925. For brief analyses, see: Investment Migration Insider interview with Dimitry Kochenov, D. Kochenov: Commission Would Likely Be "Humiliated", If CIP-Matter Goes to Court over "Genuine Links", "Investment Migration Insider", 23 Oct. 2020, https://papers.ssrn.com/sol3/papers.cfm?abstract_id=3718328 (access 18.12.2020); M. van den Brink, Investor Citizenship and EU Law: Much to Do about Nothing ?, GlobalCit blog, 30 Oct. 2020, https://globalcit.eu/investor-citizenship-and-eu-law-muchto-do-about-nothing/ (access 18.12.2020).

11 M. Sumption, K. Hooper, Selling Visas and Citizenship: Policy Questions from the Global Boom in Investor Immigration, Washington DC 2014. Cf. Transparency International UK, Gold Rush, London 2015; A. Tryfonidou, Investment Residence in the UK: Past and Future, "Investment Migration Policy Brief", no. 1/2017.

12 L.K.L. Thiele, S.T. Decker, Residence in the United States through Investment: Reality or Chimera, "Albany Government Law Review”, no. 3/2010, p. 103; E.C. Kendall, Green Cards as the Ultimate Dividends: Why Improving the US Investment Visa Program Will Encourage the Economic Recovery by Increasing Foreign Investment and Creating Fobs for Americans, "Georgetown Immigration Law Journal”, no. 27/2013, p. 580.

$13 \mathrm{M}$. Cohen, The Re-Invention of Investment Immigration in Canada and Constructions of Canadian Citizenship, "Investment Migration Research Papers", no. 2/2017.

${ }_{14}$ Cf. C. Kälin, Ius Doni, in: International and European Law, Brill-Nijhoff 2019; K. Surak, Citizenship 4 Sale, Cambridge MA 2021 (forthcoming), Cf. Citizenship and Residence Sales: Rethinking..., op. cit.

15 D. Kochenov, J. Lindeboom, Empirical Assessment of the Quality of Nationalities, "European Journal of Law and Governance", no. 4/2017, p. 314.

${ }^{16}$ Cf. e.g. A. Solimano, Global Mobility of the Wealthy and Their Assets: An Overview, "Investment Migration Research Papers", no. 2/2018; V. Popov, Why Some Countries Have More Billionaires than Others? Explaining Variety in the Billionaire Intensity of GDP, "Investment Migration Research Papers", no. 3/2018.

17 K. Surak, Global Citizenship 2.0 - The Growth of Citizenship by Investment Programmes, "Investment Migration Research Papers", no. 3/2016. In other fields specialized agencies help persons with low-quality citizenships to learn the relevant languages for the upgrade of the personal legal status; trace the necessary documents to establish the "right" ancestry leading to a European document, or facilitating giving birth abroad in the ius soli jurisdictions offering high-quality nationalities: Y. Harpaz, Citizenship 2.0: Dual Nationality as a Global Asset, Princeton 2019. 
allocated status of totalitarian domination ${ }^{18}$ should be "for sale". ${ }^{19}$ Naturalisation through investment has even been compared to the "passport trade", ${ }^{20}$ a trade which does not exist, strictly speaking, outside of the clandestine Pacific passport markets ${ }^{21}$ and other criminal circles providing counterfeited official documents. ${ }^{22}$ Nonetheless, distributing citizenship - an arbitrarily assigned and commonly inherited legal status best compared to feudal privilege ${ }^{23}$ - through this particular route has been loudly pronounced non-kosher, immoral, if not illegal, by scholars and politicians alike. ${ }^{24}$ The Commission, with its 2019 Report and the 20 October 2020 action against Malta and Cyprus, has joined this high morality camp demonstrating what Carl Baudenbacher characterised as "fragwürdige Aktionismus". 25

Pronouncements of "immorality" of citizenship "sales" do not constitute the only available approach to understanding the issue of invest-

18 D. Kochenov, Citizenship, Cambridge MA 2019.

19 A. Shachar, Dangerous Liasons: Money and Citizenship, in: Debating Transformations of National Citizenship, ed. R. Bauböck, Berlin 2018, p. 7; A Tanasoca, Citizenship for Sale: Neomedieval Not Fust Neoliberal, "European Journal of Sociology", no. 57/2016, p. 169. Cf. also J. Džankić's writings on this matter.

20 See, e.g. D. Kochenov, "Passport Trade": The Vicious Circle of Nonesense in the Netherlands, Verfassungsblog, 8 June 2020, https://verfassungsblog.de/passport-tradea-vicious-cycle-of-nonsense-in-the-netherlands/ (access 1.08.2020).

${ }^{21}$ A. Van Fossen, Citizenship for Sale: Passports of Convenience from Pacific Island Tax Havens, "Commonwealth and Comparative Politics", no. 45/2007, p. 138.

22 G. Gotev, Thousands obtained EU citizenship for $€ 5000$ in Bulgarian scam, "Euractiv", 30 October 2018, www.euractiv.com/section/justice-home-affairs/news/thousands-obtained-eu-citizenship-for-e5000-in-bulgarian-scam/ (access 21.06.2020).

${ }^{23}$ J. Carens, The Ethics of Immigration, Oxford 2013; J. Carens, Aliens and Citizens: The Case for Open Borders, "Review of Politics", no. 49/1987, p. 251. Cf., most ironically, Tanasoca, who takes an openly pro-feudal stance, denying the presumption of equal human worth and the principle of dignity, and preaching the moral superiority of aristocracy over the "common" people: A Tanasoca, Citizenship for Sale: Neomedieval not Fust Neoliberal, "European Journal of Sociology", no. 57/2016, p. 169. For a criticism, see: S. Roy, The "Streetlight Effect" in Commentary on Citizenship by Investment, in: Citizenship and Residence Sales: Rethinking the Boundaries of Belonging, eds. D. Kochenov, K. Surak, Cambridge 2021 (forthcoming).

24 European Parliament, Resolution of 16 January 2014 on EU citizenship for sale (Resolution) (2013/2995(RSP); A. Shachar, Citizenship for Sale?, in: The Oxford Handbook of Citizenship, eds. A. Shachar et al., Oxford 2019, p. 795; A Tanasoca, Citizenship for Sale: Neomedieval Not Fust Neoliberal, "European Journal of Sociology", no. 57/2016, p. 169; S. Carrera, The Price of EU Citizenship: The Maltese Citizenship-forSale Affair and the Principle of Sincere Cooperation in Nationality Matters, "CEPS Policy Brief" 2015.

${ }^{25}$ C. Baudenbacher, "Goldene Pässe"-fragwürdige Aktionismus des EU-Kommission, "Neue Züricher Zeitung”, 4 Dec. 2020, p. 19. 
ment migration, as the overwhelming popularity of investment migration among the EU Member States testifies. Indeed, acquiring residence and/or citizenship in exchange for investment or donation is a historically mainstream practice ${ }^{26}$ conducted entirely through the law and in full compliance with it. ${ }^{27}$ In any event, the tone and often the content of the engagement of numerous of my colleague scholars and politicians with this subject is reminiscent of fighting Stanley Cohen's "folk devils" - not mods or rockers in this case, but the "sellers of citizenship". ${ }^{28}$ There is also a facet of this debate which can act as a mirror - one of great importance to European societies - as investment migration unquestionably underlines citizenship's absurdity, ${ }^{29}$ by allowing those who emerged as losers in the global "birthright lottery" 30 - members of the absolute majority of the world's population $^{31}$ - to buy what others got assigned to them for free by blood, but at once also to be singled out as having uniquely undeservedly acquired this status. When the (high) price of citizenship for the randomly unlucky is made clear, the hypocrisy of citizenship's essence is instantly laid bare. ${ }^{32}$ It therefore necessarily challenges the glorificatory nationalist paradigm of contemporary citizenship regulation and citizenship studies long noted by Linda Bosniak and other scholars. ${ }^{33}$ This is where the Commission decided to start its intervention, releasing on 23 January 2019 a Report on the practice of investment migration entitled "Report on Investor Citizenship and Residence Schemes in the European Union". ${ }^{34}$

${ }^{26}$ M. Prak, Citizens without Nations, Cambridge 2018.

27 E.g. P. Weingerl, M. Tratnik, Relevant Links: Investment Migration as an Expression of State Autonomy in Matters of Nationality, in: Citizenship and Residence Sales: Rethinking the Boundaries of Belonging, eds. D. Kochenov, K. Surak, Cambridge 2021 (forthcoming).

28 S. Cohen, Folk Devils and Moral Panics: The Creation of Mods and Rockers, London 1972.

29 D. Kochenov, Citizenship for Real: Its Hypocrisy, Its Randomness, Its Price, in: Debating Transformations of National Citizenship, ed. R. Bauböck, Berlin 2018, p. 51; P. Spiro, Cash-for-Passports and the End of Citizenship, in: Debating Transformations of National Citizenship, ed. R. Bauböck, Berlin 2018, p. 17.

30 A. Shachar, The Birthright Lottery, Cambridge MA 2009.

${ }^{31}$ D. Kochenov, Citizenship, Cambridge MA 2019; Kälin and Kochenov's Quality of Nationality Index, eds. D. Kochenov, J. Lindeboom, Oxford 2020.

32 D. Kochenov, Citizenship for Real: Its Hypocrisy, Its Randomness, Its Price, in: Debating Transformations of National Citizenship, ed. R. Bauböck, Berlin 2018, p. 51.

33 L. Bosniak, The Citizen and the Alien, Princeton 2006, pp. 5-9; and further J. Tully, On Global Citizenship, London 2014. See also crucially Christian Joppke's work, virtually all of which could stand as an illustration of this point.

${ }^{34}$ European Commission, Report from the Commission to the European Parliament, the Council, the European Economic and Social Committee of the Regions $\operatorname{COM}(2019) 12$ final. 
It continued on 20 October 2020 by warning Cyprus and Malta that it is of the opinion that these countries are in breach of EU law as they grant citizenship with no regard to "genuine links", which is purportedly in breach of the duty of loyalty. Disloyalty here could be to nothing else but the purity of European blood in one's veins - limpieza de sangre $21^{\text {st }}$ century style. In the absence of unconditional ius soli, there is no way to read the Commission differently, since the whole point of "genuine links" can only be relevant in the case of those whose blood is presumed impure to provide such a link genuinely and easily in the first place. ${ }^{35} \mathrm{Pu}-$ rity of blood money cannot buy, hence, "European citizenship should not be for sale" - the opening line of the Commission's solemn moral panic hymn. Whether fuelling moral panics is among the tasks of the guardian of the Treaties is an open question for a larger debate, directly linked to Europe's justice deficit ${ }^{36}$ and the political nature of the Commission. ${ }^{37}$ Or is it simple Russophobia and the suspicion of the Chinese - the core clientele of the citizenship by investment programmes - as Baudenbacher suggested ${ }^{38}$ Numerous questions arise. What we will focus on in what follows is the substance of the Commission's legally unsound claims.

\section{Investment Migration in the EU}

As opposed to a clandestine "passport trade", investment migration - which is achieved through the acquisition of citizenship by investment (CBI) or residence by investment (RBI, often eventually leading to citizenship) - is a completely legal practice and is widespread in the EU. In a world where states themselves decide on who their citizens are

${ }^{35}$ An American descendant of a Greek great grandfather is Greek and European, she unquestionably has genuine links with Greece, since the blood is pure. An American descendent of a Greek great grandmother, on the other hand cannot boast purity of blood and has no genuine links with Greece (where citizenship is passed, until a certain point, only via the male line) and thus no genuine links with the European Union either. To preserve and reinforce this core understanding is what the Commission, essentially, hopes to deploy the duty of loyalty for. Getting her the right to be considered a European like the first American above through investment is immoral, we are told - but an Irish grandfather would be fine.

${ }^{36}$ Cf. Europe's Fustice Deficit?, eds. D. Kochenov, G. de Búrca, A. Williams, Oxford 2015 .

37 Cf. The contributions in Holding the Political Commission Accountable, ed. M. Dawson, Verfassungsblog debate, September 2018, https://verfassungsblog.de/ category/debates/holding-the-political-commission-accountable-debates/ (access 1.08.2020).

38 C. Baudenbacher, "Goldene Pässe” - fragwürdige Aktionismus des EU-Kommission, "Neue Züricher Zeitung”, 4 Dec. 2020, 19. 
(1930 Hague Convention, Article 1), cashing in on rich foreigners coming from countries issuing low-quality citizenships is an attractive prospect. ${ }^{39}$ It is not surprising that the rich are more than ready to pay a lot of money for a more dignified, more useful and often less abusive status, given the role which citizenship plays in our lives, as Branko Milanovic, inter many alia, shows in his work. ${ }^{40}$ Citizenship is an effective legal tool of harsh arbitrary punishment and exclusion ${ }^{41}-$ and the particular mode of its acquisition cannot possibly alter its essence. ${ }^{42}$

In the EU alone, direct citizenship by investment is available in Austria, Bulgaria, Cyprus (currently suspended to be reopened soon), Malta and potentially other Member States where naturalizations by parliament or the executive are exceptionally possible. As for residence, Bulgaria, Cyprus, the Czech Republic, Estonia, Greece, Spain, France, Croatia, Ireland, Italy, Lithuania, Luxembourg, Latvia, Malta, the Netherlands, Poland, Portugal, Romania and Slovakia offer (permanent) residence statuses for investment, which are often convertible into the citizenship of those Member States. In short, investment migration is practiced by the absolute majority of the EU's Member States. Once again, "Fortress Europe", alongside the US, Canada, the UK, Turkey and many Caribbean states, is a world-leading example of this type of marketised sovereignty, though others abound, from Jordan to Vanuatu and Moldova. Given the randomness of citizenship distribution, ${ }^{43}$ opposing any particular route to naturalisation would be pure hypocrisy, ${ }^{44}$ just as is citizenship itself. ${ }^{45}$ Dora Kostakopoulou is absolutely right to take issue with naturalisation's very essence, ${ }^{46}$ just as Joseph Carens has done with the idea of the ethical core of citizenship and migration boundaries. ${ }^{47}$ In a world of random citizenship, naturalisation is inescapably a ritual which has purifying deficient "others", thus their humiliation, at its essence. ${ }^{48}$ Ironically for the

${ }^{39}$ K. Surak, Millionaire Mobility and the Sale of Citizenship, "Journal of Ethnic and Migration Studies", no. 1/2021.

40 B. Milanovic, Global Inequality, Cambridge MA 2018.

${ }^{41}$ D. Kochenov, Citizensihp, Cambridge MA 2019.

${ }^{42}$ Ibidem; D. Kochenov, Citizenship for Real: Its Hypocrisy, Its Randomness, Its Price, in: Debating Transformations of National Citizenship, ed. R. Bauböck, Berlin 2018, p. 51.

43 D. Kochenov, Citizenship, Cambridge MA 2019.

44 D. Kochenov, Citizenship for Real: Its Hypocrisy, Its Randomness, Its Price, in: Debating Transformations of National Citizenship, ed. R. Bauböck, Berlin 2018, p. 51.

45 Ibidem.

46 D. Kostakopoulou, Why Naturalization?, "Perspectives on European Politics and Society", no. 4/2003, p. 85.

47 J. Carens, The Ethics of Immigration, Oxford 2013.

48 D. Kochenov, Merrouw De Fong Gaat Eten: EU Citizenship and the Culture of Prejudice, "EUI RSCAS Working Paper”, no. 6/2011. 
moral panicking few, enabling the purchase of a citizenship, in this context, is unquestionably and infinitely more respectful of the "other" than the culture and language tests imposed for other naturalisation routes, which assume by default the deficient nature of the newcomer's language and culture. ${ }^{49}$

Naturalisations of those, who are not "natural born" citizens including a sub-type of investment naturalisations, fall squarely within the realm of what is legal worldwide, including in the EU. From Hans Ulrich Jessurun d'Olivera, ${ }^{50}$ Peter Spiro ${ }^{51}$ and Jo Shaw, ${ }^{52}$ to Matjaž Tratnik and Petra Weingerl ${ }^{53}$ and Daniel Sarmiento, ${ }^{54}$ the consensus is well articulated and undisputed. In the EU it is confirmed unequivocally by the case law of the Court of Justice: ${ }^{55}$ from Micheletti and Zhu $\mathcal{E}$ Chen $^{56}$ to Tjebbes. ${ }^{57}$ If a Member State wants an investment migration programme, it can have one: the division of competences is crystal clear. ${ }^{58}$

\section{The Commission's 2019 Report: Pretending There Is No Law}

On 23 January 2019, the Commission released its "Report on Investor Citizenship and Residence Schemes in the European Union". ${ }^{99}$ The

${ }^{49}$ Ibidem (and the literature cited therein).
50 H.U. Jessurun d'Oliveira, op. cit.
51 P. Spiro, Nottebohm and "Genuine Link": The Anatomy of Furisprudential Illusion,
Investment Migration Research Papers", no. $1 / 2019$.
52 J. Shaw, Citizenship for Sale: Could and Should the EU Intervene?, in: Debating
Transformations of National Citizenship, eds. R. Bauböck, Berlin 2018, p. 61.
53 M. Tratnik, P. Weingerl, Investment Migration and State Autonomy: The Quest for
he Relevant Link, "Investment Migration Research Papers", no. 4/2019.
54 D. Sarmiento, EU Competence and the Attribution of Nationality in Member States,
Investment Migration Research Papers", no. 2/2019.
55 See, for the general analyses, D. Kochenov, J. Lindeboom, Pluralism Through its Denial, in: Research Handbook on Legal Pluralism and EU Law eds. G.T. Davies, M. Avbelj, Cheltenham 2018; H.U. Jessurun d'Oliveira, op. cit.

${ }^{56}$ Case C-200/01 Zhu and Chen, ECLI:EU:C:2004:639.

57 Case C-221/17, Tjebbes, ECLI:EU:C:2018:572. Cf. D. Kochenov, The Tjebbes Fail, "European Papers", no. 4/2019, p. 319; H.U. Jessurun d'Oliveira, Tjebbes en aanhangend nationaliteit, "Nederlands Juristenblad" 2019, p. 37; K. Swider, Legitimising Precarity of EU Citizenship: Tjebbes, “Common Market Law Review”, no. 57/2020, p. 1163.

58 On the specific issue of investment residences please see: $M$. van den Brink, Investment Residence and the Concept of Residence in EU Law: Interactions, Tensions, and Opportunities, "Investment Migration Research Papers", no. 1/2017.

${ }^{59}$ European Commission, Report from the Commission to the European Parliament, the Council, the European Economic and Social Committee of the Regions $\operatorname{COM}(2019) 12$ final. For an insightful analysis, see: C. Margiotta, Ricchi e poveri alla 
Report, containing not a single word on the benefits of investment migration to explain why the practice is widespread in the majority of the Member States and saying little about the Commission's lack of competence in the matter, criticised investment migration and investment citizenship in particular, on totally unsubstantiated grounds, misrepresenting the law of the EU as well as international law and coming to questionable conclusions in direct conflict with the case law of the Court of Justice. The Report is thus a puzzling example of a political document produced not only in oblivion of, but in direct contradiction to the law.

Given the ongoing moral panic and the resultant emotive and negative attention that the whole issue of investment citizenship and residence has been receiving from the powers that be in the European Union - be it the European Parliament ${ }^{60}$ or the individual Commissioners, from Reding's "EU citizenship should not be for sale" 61 from several years ago, to Commissioner Jourová's more recent proclamations ${ }^{62}$ - lawyers and policymakers could justifiably have expected much more from the Commission's treatment of this much inflated but hugely important topic. Though substantially fewer than $1 \%$ of all citizenships and residences granted in the EU are investment-based - a fact, which the Commission never mentions, strongly indicating that the weight given to the issue is most likely inflated - its characterisation as being of overwhelming economic and social importance clearly indicates that it deserves very serious and clear-eyed analysis. The Commission's Report fails abundantly on this count and the reasons - beyond banal political bias, overshadowing even EU law - are difficult to formulate.

The Report, which is clearly a result of a huge log-rolling exercise, will definitely not be entered on the roll of documents the Commission could even be vaguely proud of. Rather than providing a clear, rule-based analysis of the forces underlying the moral panic behind offering "for sale" the sacred status of belonging, the Report turns against the key achievements of the Union and misrepresents EU citizenship law as a nineteenth-century Blut und Boden myth, rather than a modern, globalised, forwardlooking status. The Union emerging from the pages of the Report is noth-

prova della cittadinanza europea. Annotazioni sulla Relazione della Commissione europea sui programmi di cittadinanza per investitori, "Ragion Pratica", no. 2/2020, p. 513.

${ }^{60}$ European Parliament, Resolution of 16 January 2014 on EU citizenship for sale (2013/2995RSP).

${ }^{61}$ V.Reding, Citizenship Must Not be Upfor Sale, European Commission Speech 14/18, http://europa.eu/rapid/press-release_SPEECH-14-18_en.htm (access 1.08.2020).

${ }^{62}$ E.g. Answer of Commissioner Jourová on behalf of the Commission on written question, E-005960/2017. 
ing short of Hamsunian, full of "nature", "genuine links" and "real" citizenships, based on long-dead, repugnant ideals and thus impossibly dull. Given that there is no legal basis in the TEU or TFEU for the pursuit of a "natural" citizenship myth as it once was - as discussed by Spiro, ${ }^{63}$ Joppke ${ }^{64}$ and others, it does not come as a surprise that the Commission resorts to obsolete legal authority and abundant, flawed legal reasoning to sell the untenable position that it has no legal basis properly to defend. One wonders why the legal service did not get a chance to see the document in draft: the Commission's position, in assuming "genuine links" between states and citizens, is not only flawed in terms of international law - as will be discussed below - but it also falls short of the "market citizenship" standard, however criticized.$^{65}$ If conditioned on such "genuine links", free movement of EU citizens would be endangered, if not impossible, which is precisely the reason why AG Tesauro laughed at the embarrassing position embraced by the Commission in the ancient Micheletti case. ${ }^{66}$

The Report is correct on many of the facts it communicates: 20 or more (i.e., more than 70\%) Member States opted for a policy which the Commission has no direct competence to regulate, ${ }^{67}$ but tackles in the Report. This alone makes the Commission's take on investment migration worth looking at in some detail: what is on the Commission's mind? The analysis that the Commission provides is flawed on at least five levels, briefly dealt with below. The outcomes are instructive: as the Member States have largely ignored this pas by the Commission, the institution has been toning down its most absurd claims in the months that followed the Report's release, as Luuk van der Baaren reports. ${ }^{68}$ This toning down phase proved to be short-lived, however, as the moral panic report parading as law provided the foundation of the 20 October 2020

${ }^{63}$ P. Spiro, Cash-for-Passports..., op. cit., p. 17.

${ }^{64}$ C. Joppke, Citizenship and Immigration, Cambridge 2010; C. Joppke, The Instrumental Turn of Citizenship, "Journal of Ethnic and Migration Studies”, no. 44/2018, p. 1.

65 See, for the best available analysis: C. O'Brien, Unity in Adversity, Oxford 2017. See also D. Kochenov, The Oxymoron of "Market Citizenship" and the Future of the European Union, in: The Internal Market and the Future of European Integration: Essays in Honour of Laurence W. Gormley, ed. F. Amtenbrink et al., Cambridge 2019, p. 217 (and the literature cited therein).

${ }^{66}$ Opinion of AG Tesauro in Case C-369/90 Micheletti [1992] ECR I-4239, para 5.

${ }^{67}$ D. Sarmiento, EU Competence and the Attribution of Nationality in Member States, "Investment Migration Research Paper", no. 2/2019.

${ }^{68}$ L. van der Baaren, Investor Citizenship and State Sovereignty in International Law, in: Citizenship and Residence Sales: Rethinking the Boundaries of Belonging, eds. D. Kochenov, K. Surak, Cambridge 2021 (forthcoming). 
action by the Commission against two of the smallest Member States among dozens practicing investment migration. All the flaws found in the Report and dissected below thus left the realm of relatively abstract scribbles and are being turned by the Commission into the tools to bully the smallest Member States. The bullying tools are referred to as such here simply because what the Commission lists are not legal arguments. Worse still, should these be legal arguments, a successful operation of EU citizenship and the fundamental principle of non-discrimination on the basis of nationality in the internal market would need to be set aside in favour of high nationalism ideals where blood is "pure" and citizenship is "natural".

\section{Flaw no. 1: Framing investment uniquely as a risk, rather than an opportunity}

Undoubtedly, there is a fundamentally important issue to hand: investment migration is capable of bringing huge gains, but also brings with it potential risks. The Commission is dead silent on the former, presumably deferring to the over $70 \%$ of the Member States on this crucial issue, but is absolutely right about mentioning the latter. When practiced in non-transparent and corrupt ways, investment migration - like any other enterprise - will certainly generate problems that have to be tackled. These precisely involve corruption, money laundering and tax evasion - not naturalisation as such. The Commission's Report fails to make this basic distinction. On this count, banking, mining or gambling - to name but a few corruptible enterprises - could be frowned upon - yet when we regulate banks, casinos or mines, we do not presume that these activities should be outlawed; precisely the presumption the Commission harbours in the Report on investment migration and pushes in its action against Cyprus and Malta. It presents the whole issue of investment migration uniquely as a risk, rather than as an opportunity. In particular, the Commission speaks of the risks regarding "security, money-laundering, tax evasion and corruption". ${ }^{69}$

The fact that twenty Member States offer residence, residence leading to citizenship or citizenship directly, for donations or investments, as the

${ }^{69}$ Commission's Report, p. 2. Crucially, research shows that unlike reversing the key EU citizenship law of the ECJ, which the Commission hints at in the report when invoking "genuine links", it has full competence to address money laundering, tax evasion, corruption threats and other issues usually mentioned in the context of the moral panics surrounding investment migration: D. Sarmiento, M. van den Brink, EU Competence and Investor Migration, in: Citizenship and Residence Sales: Rethinking the Boundaries of Belonging, eds. D. Kochenov, K. Surak, Cambridge 2021 (forthcoming). 
Commission correctly reports, makes it clear that the cost and benefit analysis has been conducted differently by at least twenty governments which have opted to introduce the schemes with the benefits to be reaped in mind..$^{70}$ This makes the Commission's complete silence on the potential benefits of such schemes in terms of investment very problematic. It is certainly a field worth studying. It could definitely be the case that there is no flow of FDI triggered specifically by an investment migration scheme in certain countries. Sumption and Hooper have shown ${ }^{71}$ for instance, that UK Tier 1 visas - incidentally, like the one revoked from Roman Abramovich and leading to the loss of inter alia a billion pounds of investment into a new stadium - a visa type which formally requires the purchase of government bonds, do not affect the country's economic performance. This statement cannot be true for all the twenty jurisdictions, however. Consider applying this analysis to countries requiring a donation, such as Malta, rather than an investment, with its expected return. While in Cyprus, for instance, it could indeed be the case - however doubtful the hypothesis - that for some reason, even more Russian or Chinese money would have passed through the island's banks without it having citizenships on offer, in the case of Malta it is absolutely clear that the contributions, which are paid in exchange for citizenship, would not under any circumstances whatsoever, have been made without the Malta Individual Investment Programme offering the service for which the money is paid.

To put it differently, what the Commission chose not to mention or quantify is a share of Malta's GDP and the results of the analyses conducted by the twenty Member States of the EU which underpinned their respective decisions to introduce investment migration programmes in national law. In other words, the complete silence concerning the benefits which the overwhelming majority of the EU Member States either receive or believe to be receiving from investment migration, unquestionably casts the Commission's work in a deeply biased light. The Commission's suggestion seems to be that twenty Member States are all behaving deeply irrationally, which is implausible and thus absurd on its face. Without denying the potential risks, which are rightly pointed out by the Commission, it is nevertheless possible to assert that the aim of the Report is

70 This being said, what amounts to a "success" of an investment migration programme is, of course, a complex and multi-faceted issue: M. Sumption, Can Investor Residence and Citizenship Programmes Be a Policy Success?, in: Citizenship and Residence Sales: Rethinking the Boundaries of Belonging, eds. D. Kochenov, K. Surak, Cambridge 2021 (forthcoming).

${ }^{71}$ M. Sumption, K. Hooper, op. cit. 
the misrepresentation of investment migration, given that, notwithstanding the fact that the title of the Report mentions citizenship and investor residence schemes, it is entirely silent, precisely, on the raison d'être of both - investments - something that should have rather been the starting point of any serious analysis. This is the first count on which the Commission has failed.

\section{Flaw no. 2: An incompetent hymn to blood and soil}

The Commission claims to have discovered what citizenship is about, writing that citizenship "is traditionally based on [...] ius sanguinis and [...] ius soli". ${ }^{72}$ This is all correct, but the Devil, as is only so frequently the case, is in the details. In giving its "golden standard", the Commission does not make it clear that:

a) it does not have the power to regulate this area;

b) the reality is much more complex than what its selective summary purports to demonstrate.

The combination of the two is extremely problematic, befogging the crucial issue of citizenship acquisition rules to a great degree and enabling the Commission to squeeze in several bizarre, legally obscurantist claims into the text of the Report only for these to reappear in the context of probing the legal action against two of the smallest Member States.

Referring to citizenship by investment, the Commission writes that, in essence, such "citizenship is granted under less stringent conditions than under ordinary naturalization regimes". ${ }^{73}$ What is crucial here is to mention the different ways that the citizenship law of all the Member States rationally accommodate enabling the acquisition of citizenship by different categories of applicants. Also of importance is the sovereignty/competence aspect of this story. Starting with the latter, states are free to confer citizenship on those whom they consider qualified under the Hague Convention of Nationality (Article 1) and, unquestionably, under EU law - as Shaw,${ }^{74}$ myself ${ }^{75}$ and most recently, Jessurun d'Oliveira, ${ }^{76}$ Sarmiento ${ }^{77}$ and

72 Commission's Report, p. 3.

${ }^{73}$ Ibidem, p. 2 (emphasis added).

${ }^{74}$ J. Shaw, Citizenship for Sale: Could and Should the EU Intervene?, in: Debating Transformations of National Citizenship, ed. R. Bauböck, Berlin 2018, p. 61.

75 D. Kochenov, Rounding up the Circle: The Mutation of Member States Nationalities under Pressure from EU Citizenship, "EUI RSCAS Working Paper”, no. 23/2010.

${ }^{76}$ H.U. Jessurun d'Oliveira, op. cit.

77 D. Sarmiento, EU Competence and the Attribution of Nationality in Member States, "Investment Migration Research Papers", no. 2/2019. 
Tratnik and Weingerl ${ }^{78}$ have demonstrated. By extension, this applies to EU citizenship, which is a derivative - ius tractum - citizenship. ${ }^{79}$ No sane academic voice would be able to argue that the EU has competence to legislate here, which is why the Report is not a legislative proposal and will never become one. It will not surprise the reader to learn that France still decides on who is French and retains all the rights to do so, just as Malta decides on who is Maltese and Finland on who is Finnish. The law is crystal-clear, just like the fact that all the Member States find the continuation of this approach vital to their interests - which makes the Commission's Report look like a poorly orchestrated attempted power-grab. It is impossible to propose the rigid framework that the Report purports to have found (ius sanguinis + ius soli + "genuine links") for establishing any mode of acquisition of citizenship, in an area where the Commission has no say in law, but the aspiration is clear. To present Malta, Cyprus or Bulgaria as breaching the fundamental principles of EU law would have been going too far: they use their legal competence to naturalise third-country nationals in strict accordance with the law. This is exactly why the Commission merely uses a negative tone to refer to these activities, instead of explaining what is wrong with them. The answer is: nothing is wrong and the tone is unacceptable. Consequently, the reasons for mentioning that "these schemes are explicitly advertised as a means of acquiring EU citizenship" 80 are unclear, since the schemes are precisely created to make new EU citizens - nothing more and nothing less.

EU law is funny in a way - and this is its unquestionable, pluralist strength. ${ }^{81}$ A US kid able to find a Greek great-great-grandfather can become an EU citizen automatically without ever visiting Greece; the spouse of a Frenchman in Vietnam can naturalise without ever having lived in France or Europe, an EU citizen does not need to renounce her original nationality when naturalising in Germany, unlike any Turk or a Russian with no EU citizenship, and a Catholic dignitary retiring from the Vatican becomes an Italian automatically and immediately, all of them not under "less stringent conditions", but because these are groups treated differently by immigration and citizenship law in the Member States concerned.

${ }_{78}$ M. Tratnik, P. Weingerl, Investment Migration and State Autonomy: The Quest for the Relevant Link, "Investment Migration Research Papers”, no. 4/2019.

${ }^{79}$ D. Kochenov, Ius Tractum of Many Faces: European Citizenship and the Difficult Relationship between Status and Rights, "Columbia Journal of European Law", no. 15/2009, p. 169.

${ }^{80}$ Commission's Report, p. 2.

${ }^{81}$ D. Kochenov, J. Lindeboom, Pluralism Through its..., op. cit. 
Perusal of any citizenship law book makes as much clear: when we speak about the acquisition of citizenship, differentiated treatment of different cases is key. It is an essential and characteristic part of nationality regulation. Member States establish what is desirable and while Italy has decided that asking an ailing Japanese Cardinal - stateless upon retirement from Vatican service - to wait the usual 10 years to become Italian is undesirable, replacing it with zero years instead, and the Dutch government has decided that asking asylum seekers to wait as long as others to naturalise would be unkind, the Maltese government makes the grant of nationality conditional on a significant donation to drive the economy of the island. In the light of the existing differences in procedure, underpinned by great disproportion in the numbers, where hundreds of thousands became EU citizens through extremely remote ancestry or other ways having nothing to do with the state or its "culture" through the laws of Bulgaria, Greece, Ireland, Italy, Romania and other states, stating that investment citizenship is 'less stringent', as the Commission does, is an absurd misrepresentation.

To drive this point home, it is even more absurd than it first seems at least for two reasons. Most importantly, all other ways to acquire citizenship do not require a significant investment. An American kid, like the son of a Venezuelan friend, searching through archives for any Greek connections so as to avoid paying US-rate tuition fees at Bologna Medical School, is not bringing several million to Greece. To imply that undying Greekness can persist across six generations, however much ethnonationalist and passé a notion this might be, is a decision for the Greek government to take, which fits the general international trends, as Christian Joppke has shown. ${ }^{82}$

So the Cypriot choice to create citizens through investment is at least as rational (or irrational) as the Greek, but not to a protestor in the "Macedonia is Greece" crowds of course, ${ }^{83}$ which our US kid, thankfully, will never join. The question of what is "legal" does not arise, since it is not up to the Commission to ask or comment on and given that international law, just like European law, is clear: Member States will decide as they see fit. So for Malta EUR 650,000 was more important than nationalism, while for Greece the opposite is true. Some would applaud this choice:

${ }^{82}$ C. Joppke, Citizenship between De- and Re-Ethnicization, "European Journal of Sociology", no. 44/2003, p. 429.

${ }^{83}$ Z. Rahim, Athens riots: Clashes as 60,000 protesters march in Greece against Macedonia name change, "Independent" 2019, https://www.independent.co.uk/news/world/ europe/athens-protests-violence-riots-police-officers-macedonia-name-change-prespes-agreement-a8737581.html (access 22.06.2020). 
"Greek blood is important!" To suggest, however, that some other choice is somehow "less legal" cannot be correct. And morality has never played a role in citizenship law, especially in the EU, with its colonial past ${ }^{84}$ and essentially race-based exclusion from EU citizenship ${ }^{85}$ approved by the ECJ in Kaur. ${ }^{86}$ Globally the picture is no different: citizenship is the main tool for the preservation of global inequality at the moment, as Branko Milanovic, once again, has explained. ${ }^{87}$

Secondly, and equally importantly, "ordinary conditions" - as opposed to the frowned-upon "less stringent" ones - imply a level of due diligence which is significantly lower than what investment citizenship promises: the entirety of one's finances and business connections, as well as your entire life history would not normally be dug up by independent due diligence providers, unless you are an investor naturalising on that ground. ${ }^{88}$

This is only right: different applicants require different standards. The absurdity of implying, as the Commission does, that investing several million and going through deep scrutiny is less stringent than finding a Greek man whom you have never met in one's ancestry (citizenship has traditionally been sexist, of course), ${ }^{89}$ speaks for itself. This begs the conclusion that the 'context' of citizenship acquisition, to which the Commission dedicated a whole section in its Report, ${ }^{90}$ is misleading: forgetting to mention "difference" amounts to failing to tell a true story. The Commission has thus failed at the most basic level, and is unable to present the fundamental rules for the acquisition citizenship.

${ }^{84}$ P. Hansen, S. Jonsson, Eurafrica: The Untold Story of European Integration and Colonialism, London 2014.

85 Lord A. Lester, Thirty Years on: The East African Case Revisited, "Public Law", no. $47 / 2002$, p. 52.

86 Case C-192/99 Kaur [2001] ECR I-01237; H. Toner, Annotation Case C-192/99 Kaur [2001], “Common Market Law Review”, no. 39/2002, p. 881. Cf. D. Kochenov, Ius Tractum of Many Faces, "Columbia Journal of European Law”, no. 15/2009, p. 169.

87 B. Milanovic, Global Inequality, Cambridge MA 2016.

${ }^{88}$ M. Corrado, K. Marsh, Investment Migration and the Importance of Due Diligence: Examples of Canada, Saint Kitts and Nevis, and the EU, in: Citizenship and Residence Sales: Rethinking the Boundaries of Belonging, eds. D. Kochenov, K. Surak, Cambridge 2021 (forthcoming).

89 J. Abrams, Examining Entrenched Masculinities in the Republican Government Tradition, "West Virginia Law Review", no. 114/2011, p. 165.

${ }^{90}$ Commission's Report, Section 2.1, pp. 3, 4. 


\section{Flaw no. 3: Flawed reasoning rooted in obsolete authority of 'genuine links'}

The third main flaw of the Report after misrepresenting the investment migration it purports to describe and failing to summarise the basics of citizenship acquisition rules, is the Commission's failure to come to terms with the basic meaning of citizenship in law as an abstract legal status. Rogers Brubaker famously defines citizenship as an "object and instrument of closure", ${ }^{91}$ that is: selecting those who "belong" from the available number of bodies and guarding the selected few from those who do not "belong". It means that not caring about the county and its purported "values" will not make you less of a citizen in the eyes of the law, just as caring a lot about some officially endorsed "culture" or language will not make you a citizen, unless you are named as such by law. Pretending that this is not the case - and many countries go to absurd lengths with this - like my own Kingdom ${ }^{92}$ - is deeply unhelpful. It is, nevertheless, what citizenship is designed to do - presented to us as "natural" a legal status which deprives those not endowed with it of any voice, discarding their dignity in the majority of cases, and which shields those who proudly and officially "belong" of any trifling criticism from the status quo. When the Commission informs us that "the study looked at other factors [...] which might arguably create a link between the applicant for citizenship and the country concerned", ${ }^{93}$ a citizenship lawyer reading it might well be puzzled. It is fundamental to realise that only citizenship can be such a link. To present citizenship - an abstract legal status - as something that requires more than itself in order to be enjoyed is not faithful to the letter and the spirit of global citizenship law as it stands today. The Commission's analysis carries with it a whiff of the totalitarianism of nineteenth century approaches to allegiance. ${ }^{94}$

It is impossible, with recourse to the law in force, to justify the Commission's position, since it would mean that all that the EU stands for: liberal values, non-discrimination on the basis of nationality, human dignity and equality, can be undone on the basis of tired and unambiguous 1992.

${ }_{91}$ R. Brubaker, Citizenship and Nationhood in France and Germany, Cambridge MA

92 D. Kochenov, Mevrouw De Fong Gaat Eten: EU Citizenship and the Culture of Prejudice, "EUI RSCAS Working Paper", no. 6/2011. Please note that the situation has become much worse since the paper has been written, as the level of absurdity and humiliation to which those willing to get the local documents are subjected has risen sharply.

${ }_{93}$ Commission's Report, p. 5.

${ }^{94}$ Cf. D. Kochenov, Citizenship, Cambridge MA 2019. 
nationalist tropes such as "links" with states and "cultures" pre-approved by the powers that be. The whole point of the text of the Report which emerges is the Commission's apparent desire to play handmaiden to such a totalitarianism: is this Maltese a "real" Maltese? What if he has never visited the European Union? And what about this Irishwoman?95 And this Brit? ${ }^{96}$ This Dutch ${ }^{97}$ This is where the obsolete case law of the International Court of Justice (!) - expressly overruled by the EU's own Court of Justice - comes into play: the Commission refers quite extensively to the Nottebohm theory of "genuine links". ${ }^{98}$

It could of course be possible that the Commission's desk officers might be unaware of the fact that the case was opposed immediately after it was decided by Jones, Kunz, Panhuys, and Weis - the list of authorities could be continued ad infinitum - and later dismissed by René de Groot, Jessurun d'Olivera, Macklin, Sloane, Thwaites, Vermeer-Kunzli and many others, as Spiro has splendidly summarised. ${ }^{99}$ What they could not overlook, however, is that "genuine links" are incompatible with a world which has moved on, at least officially, from perpetual allegiance and glorious mystifications of blood nationalism, as the Court of Justice confirmed in Micheletti. ${ }^{100}$ As per Advocate General Tesauro, the "romantic period of international relations" 101 is over. It is thus quite unacceptable,

${ }^{95}$ Case C-434/09 McCarthy v Secretary of State for the Home Department [2011] ECR I- 3375.

${ }_{96}$ Case C-192/99 Kaur [2001] ECR I-1237.

97 C-221/17, Tjebbes and Others, ECLI:EU:C:2019:189; D. Kochenov, The Tjebbes..., op. cit., p. 319; K. Swider, op. cit., p. 1163.

${ }_{98}$ Nottebohm (Judgment) [1955] ICJ Rep 4. The citizenship of Lichtenstein held by Mr Nottebohm was not recognised by Guatemala, the latter state treating Mr Nottebohm as a German citizen - a status he did not hold. The ICJ agreed with this restrictive vision, ruling that nationality is a "legal bond having as its basis a social fact of attachment, a genuine connection of experience, interests and sentiments, together with the existence of reciprocal rights and duties". The ICJ failed to mention, however, that in the absence of any other nationality but that of Liechtenstein and with "genuine link" only to Guatemala, precisely the state aggressing him, Mr Nottebohm was deprived of any remedy as a result of the controversial decision, even if limited only to the recognition of nationality for the purposes of diplomatic protection. To see the incoherence of the judgement, see the Dissenting Opinion of Judge Klaestad and the dissenting opinion of Judge Read. For analysis see the literature recommended in A. Bleckmann, The Personal furisdiction of the European Community, “Common Market Law Review” no. 17/1980, pp. 467, 477 and note 16.

${ }_{99}$ P. Spiro, Nottebohm and "Genuine Link..., op. cit. Please see the extensive literature cited therein.

${ }_{100}$ Case C-369/90 Micheletti [1992] ECR I-4239, I-4262.

101 Opinion of AG Tesauro in Case C-369/90 Micheletti [1992] ECR I-4239, I-4262. 
in the respectful opinion of this author, to provide a reference to "genuine links" and Nottebohm in an official Report of the European Commission as a reference to the necessity to have nationality acquired by naturalisation recognized in the "international arena". ${ }^{102}$ The reference is flawed, since the Court of Justice of the European Union has expressly prohibited the Member States from relying on Nottebohm in dealing with each other's nationals. The Report contradicts itself, of course, since this fact is mentioned in footnote $30 .{ }^{103}$ You cannot have a rule of recognition "in the international arena", which is at the same time expressly prohibited by the highest EU Court, with the immediate effect, of course, of blocking Nottebohm in the territory of the EU. This point is absolutely crucial: the Commission's Report knowingly misrepresents EU law.

References to the obsolete authority only start the Commission's puzzling campaign of putting legal reasoning to sleep. The Report essentially claims that since checking "genuine links" is expressly prohibited by EU law in Micheletti (again, mentioned correctly in a footnote), ${ }^{104}$ Member States have to ensure that such links exist. ${ }^{105} \mathrm{~A}$ prohibition is turned into an implied obligation. In outlawing any such links in Micheletti the Court of Justice has apparently instructed someone - in the mind of the Commission - to check whether the "genuine links" are there. This could not be further from the truth. Quite to the contrary, the Court has in fact clarified that "genuine links" do not apply in the context of the EU and that Nottebohm is bad law: the desk officers should check a textbook (any from this millennium would do). It is settled case law that no residence in any Member State is required in order for EU citizens to use the free movement rights protected by EU law. The Commission is trying, in its Report, to use precisely the prohibition against checking 'genuine links' unequivocally expressed directly by the Court of Justice itself as a pretext to imply that there is an obligation to check the existence of such links, presumably on the quiet. Harry Frankfurt's "On Bullshit" 106 is at least only a philosophical joke, even though not more than mildly entertaining, while the Commission's text purports to be a serious effort aimed at informing policy decisions. Nottebohm is unquestionably bad law and the Commission was obliged to know this to be the case. The Commission's reasoning amounts to trying to undermine the internal market, established case law on the free movement of persons, and the rule of EU law

${ }^{102}$ Commission's Report, pp. 5, 6.

103 Ibidem, p. 7.

${ }^{104}$ Ibidem, p. 6.

105 Ibidem.

${ }^{106}$ H. Frankfurt, On Bullshit, Princeton 2005. 
established in Micheletti. The Commission thus knowingly attempts to mislead the European Parliament, the Council, the European Economic and Social Committee and the Committee of Regions, to whom the Report is addressed, for political reasons. It could even be regarded as an example of the violation of the duty of loyalty, were the Report more convincing. ${ }^{107}$

\section{Flaw no. 4: Curious assumptions about the connection between residence, citizenship, and security}

It is when looking for possible solutions to the risks identified in terms of security, tax evasion and money laundering, however, that the Report reaches the level of the truly esoteric, which becomes scary, rather than entertaining. The Commission's analysis seems to be based on the assumption, which is nowhere explained or defended properly, that presence in one of the Member States for a period of time before naturalisation is likely to alleviate the security risks posed by a naturalised person. It is impossible to make a convincing argument that going through the one particular naturalisation procedure the Commission might have in mind makes one a less dangerous person. In fact, for as long as newly created Maltese billionaires do not stab people at Christmas markets or ram vans into crowds, the assumption entertained by the Commission rests unproven.

This also undermines the appeal of the Commission's findings that "this means that applicants can acquire citizenship of Bulgaria, Cyprus or Malta - and hence EU citizenship - without ever having resided in practice in the Member State". ${ }^{108}$ The only answer to this is "of course!" in a situation where hundreds of thousands of EU citizens have never been to the $\mathrm{EU}$ in their lives and there is no legal requirement, either in the EU or in International law, to bother to visit one's country of citizenship. Indeed, not everyone is fond of their grandparents' graves. Even moving beyond this obvious reality is ground well-known to the Commission: EU citizenship does not have independent grounds of acquisition. This means that - just as with the Greek, Irish or French citizenship that it would be derived from - it is entirely incorrect to imply that it requires any residence anywhere in particular. What it requires in fact, is the observance of the law - French, Irish, or Cypriot - democratically passed by

107 The duty of loyalty does not only apply to the Member States, but is owed equally by the Commission to the EU and other organs and institutions. Cf. e.g. M. Klamert, The Principle of Loyalty in EU Law, Oxford 2014.

${ }^{108}$ Commission's Report, p. 5. 
the relevant Parliament. Moreover, the continued possession of citizenship is not dependent, unlike the global practice until half a century ago, on residence in any particular territory. ${ }^{109} \mathrm{EU}$ citizens born in Chicago with this status will remain EU citizens even if they never visit the EU. If they do, no due diligence or security checks will be conducted to ascertain their right to retain their citizenship, of course. This is the most basic context in which all citizenships in the world operate: citizenship does not require residence and residence does not mean that someone is somehow rendered less of a threat. The Commission's flawed analysis is thus consistent throughout in its absolute ignorance of the subject matter of the Report that the institution has published.

\section{Flaw no. 5: Other important misrepresentations of EU Law}

Lastly - throughout the Report the Commission underlines the risks related to the freedom of movement between the Member States of these new citizens after their naturalisation. There is a problem here. Framing the use of the most important right of citizenship under EU law uniquely as a risk is not entirely correct. What could be mentioned - following Christian Kälin ${ }^{110}$ - is that all the individuals naturalised through citizenship by investment are in fact ideal EU citizens in the light of Directive 2004/38: they will never be a burden on the social security systems of the host Member States and will obviously have comprehensive health insurance - the two core requirements to be met in order to benefit from the free movement right under Article 21 TFEU. Also the Report's wording about "circumventing certain nationality requirements"111 is unhelpful and is no doubt a misunderstanding: naturalisation by investment makes one a citizen of Malta, i.e. it is a vehicle for meeting the requirement of nationality, not circumventing it. Becoming a citizen - either through marriage to a Dutch lady or serving in the French foreign legion or retiring from the Vatican - cannot be equated with circumventing a requirement of nationality. Most worryingly, the Commission seems to hint at

109 This being said, possessing two or more nationalities can suddenly activate this old rule to punish multiple citizens for being themselves, something that the Court of Justice is absolutely fine with, as Tjebbes has demonstrated: D. Kochenov, The Tjebbes..., op. cit., p. 319. For an analysis of the possible broader negative implications of holding multiple nationalities in the context of EU law, see: D.A.J.G. de Groot, Free Movement of Dual EU Citizens, in: European Citizenship under Stress: Social Fustice, Brexit, and Other Challenges, eds. N. Cambien, D. Kochenov, E. Muir, Boston 2020.

${ }^{110}$ C. Kälin, op. cit.

111 Commission's Report, p. 17. 
discrimination on the basis of how citizenship was acquired, which is prohibited in EU law since the Boukhalfa case law, ${ }^{112}$ which it does not cite, not to mention the European Convention on Nationality, on which it is equally silent.

Leaving Boukhalfa aside, the Commission has had problems brushing up on its knowledge of Directive 2003/109 as well, it appears, as several Member States are implicitly criticised for establishing an easier way to access their national Permanent Residence than the requirement of that Directive provides. ${ }^{113}$ This criticism is unacceptable, since Directive 2003/109 states unequivocally in Article 13 that: "Member States may issue residence permits of permanent or unlimited validity on terms that are more favourable than those laid down by this Directive" (emphasis added). To be absolutely clear: to imply that the Directive establishes the minimum threshold for defining permanent residence in the EU - as Sergio Carrera quite embarrassingly has done ${ }^{114}$ - is absolutely incorrect, since the text of the provision above is quite clear. It is of course true that national requirements, which are more lenient that those set out in Directive 2003/109 will not produce EU-level rights for the holders of these permits, a point covered in the literature by Martijn van den Brink, ${ }^{115}$ but this is not the general point the Report seems to be making. The Report is taking issue, erroneously, with the low physical presence thresholds under national legislation on investment residence in Malta, Greece and Bulgaria. Once again: this criticism is moot, since the Directive expressly allows the Member States to set the presence requirement at zero (" 0 ") days. This is the law the Commission is there to respect, uphold and promote. In fact, it is unclear why it is criticising the decisions legitimately taken by three Member State governments clearly within their realm of competence and breaching no legal rules while showing no evidence whatsoever of any abuse of the law besides its own relentless ignorance.

112 Case C-214/94 Boukhalfa ECLI:EU:C:1996:174. Although the Report recognises the importance of non-discrimination on this ground, it is written based on the presumption of the necessity to discriminate, which follows from its questionable 'genuine links' logic in the context of granting nationalities acquired by naturalisation an effect. Under this approach, outlawed by the Court of Justice, Miss Boukhalfa could have had no genuine links with Germany to allow her to be protected from discrimination.

${ }_{113}$ Commission's Report, pp. 8, 9.

114 S. Carrera, op. cit., p. 18.

115 M. van den Brink, Investment Residence and..., op. cit. 


\section{Conclusion: Berlaymont is Taking us for a Ride}

The Commission has proven Harry Frankfurt right: "One of the most salient features of our culture is that there is so much bullshit". ${ }^{116}$ It has taken us for a ride, nineteenth century style, telling twenty Member States that they are most likely doing it wrong, while enjoying no competence to regulate the field and demonstrating rather poor command of the matter in question. There are excellent lawyers at the Commission and the matter of "genuine links" belongs to the dullest footnotes of old textbooks, which point in one direction: the Commission's decision to misrepresent the law and go against the non-discrimination essence of EU citizenship to attempt to enlarge own Competences is but a dangerous political game. On 20 October 2020 the Commission started to push even harder, by waving threats to go to Court in a case it knows is a flop.

Many will no doubt be surprised by this - is this really what the Commission is for? - while Blood and Soil communitarians of all sorts will cheer. Beyond the haphazard argumentation and wilful misinformation concerning citizenship in general and EU citizenship in particular, the Report, just as the 20 October 2020 press release sends a very clear message: the Commission wants to regulate citizenship, telling France who is a Frenchmen and Estonians who has "genuine links" to Estonia. It is quite offensive of course, given the values the Union stands for, and not merely disappointing, that the Commission could believe in "genuine links", and express itself to be ready to sacrifice the core principles that the EU is based on. Yet, the Commission might be wrong thinking that it is too big and powerful next to Cyprus and Malta to be worried about losing face over a trivial matter of who might properly be regarded as European and who is owed dignity and respect in the EU. In the Union priding itself as an embodiment of integration through law pretending that the law does not exist or matter only to further the political interests underpinning a moral panic is a game which is much more dangerous than it would seem at the first glance. EU citizenship is as valuable as it is fragile and interpreting it in the despicable Blut und Boden way of "genuine links", i.e. by denying its bearers human dignity, will kill it.

\section{Acknowledgment}

The earlier version of this paper appeared as a working paper in the series 'Europe in Question' of the London School of Economics and Po-

${ }^{116}$ H. Frankfurt, op. cit., Introduction. 
litical Science. The author is grateful to the anonymous reviewers (also at the LSE) and to Professors Costanza Margiotta and Wojciech Sadurski for their engagement and feedback.

\section{References}

Abrams J., Examining Entrenched Masculinities in the Republican Government Tradition, "West Virginia Law Review", no. 114/2011.

Bansak K., Hainmueller J., Hangartner D., How Economic, Humanitarian, and Religious Concerns Shape European Attitudes toward Asylum Seekers, "Sciene", no. 354(6309)/2016, DOI: https://doi.org/10.1126/science. aag2147.

van der Baaren L., Investor Citizenship and State Sovereignty in International Law, in: Citizenship and Residence Sales: Rethinking the Boundaries of Belonging, eds. D. Kochenov, K. Surak, Cambridge University Press, Cambridge 2021 (forthcoming).

Baudenbacher C., "Goldene Pässe”-fragwürdige Aktionismus des EU-Kommission, "Neue Züricher Zeitung" 2020.

Bleckmann A., The Personal Furisdiction of the European Community, "Common Market Law Review", no. 467(17)/1980.

Bosniak L., The Citizen and the Alien, Princeton University Press, Princeton 2006.

van den Brink M., Investment Residence and the Concept of Residence in EU Law: Interactions, Tensions, and Opportunities, "Investment Migration Research Papers", no. 1/2017.

van den Brink M., Investor Citizenship and EU Law: Much to Do about Nothing?, GlobalCit blog, 30 Oct. 2020.

van den Brink M., Revising Citizenship within the European Union: Is a Genuine Link Requirement the Way Forward?, "EUI Working Papers RSCAS", no. 76/2020.

Brubaker R., Citizenship and Nationhood in France and Germany, Harvard University Press, Cambridge MA 1992.

Carens J., Aliens and Citizens: The Casefor Open Borders, "Review of Politics", no. 251(47)/1987, DOI: https://doi.org/10.1017/S0034670500033817.

Carens J., The Ethics of Immigration, Oxford University Press Oxford 2013. Carrera S., The Price of EU Citizenship: The Maltese Citizenship-for-Sale Affair and the Principle of Sincere Cooperation in Nationality Matters, "CEPS Policy Brief” 2015, DOI: https://doi.org/10.1177/1023263X1402100302.

Citizenship and Residence Sales: Rethinking the Boundaries of Belonging, eds. D. Kochenov, K. Surak, Cambridge University Press, Cambridge 2021 (forthcoming). 
Cohen M., The Re-Invention of Investment Immigration in Canada and Constructions of Canadian Citizenship, "Investment Migration Research Papers", no. 2/2017, DOI: https://doi.org/10.2139/ssrn.3613249.

Cohen S., Folk Devils and Moral Panics: The Creation of Mods and Rockers, MacGibbon and Kee, Grenada 1972.

Corrado M., Marsh K., Investment Migration and the Importance of Due Diligence: Examples of Canada, Saint Kitts and Nevis, and the EU, in: Citizenship and Residence Sales: Rethinking the Boundaries of Belonging, eds. D. Kochenov, K. Surak, Cambridge University Press, Cambridge 2021 (forthcoming).

Davies G., Nationality Discrimination in the Internal Market, Kluwer Law International, The Hague 2013.

Dawson M., Holding the Political Commission Accountable, Verfassungsblog debate, 2020.

Europe's Fustice Deficit?, eds. D. Kochenov, G. de Búrca, A. Williams, Hart Publishing, Oxford 2015.

Frankfurt H., On Bullshit, Princeton University Press, Princeton 2005.

Ganty S., Lintégration des citoyens européens et des ressortissants de pays tiers en droit de l'Union européenne. Critique d'une intégration choisie, Larcier, Paris 2021.

Gotev G., Thousands obtained EU citizenship for $€ 5000$ in Bulgarian scam, Euractiv, 30 October 2018.

de Groot D., Free Movement of Dual EU Citizens, in: European Citizenship under Stress: Social Fustice, Brexit, and Other Challenges, eds. N. Cambien, D. Kochenov, E. Muir, Brill-Nijhoff, Boston 2020.

Hansen P., Jonsson S., Eurafrica: The Untold Story of European Integration and Colonialism, Bloomsbury Academic, London 2014.

Harpaz Y., Citizenship 2.0: Dual Nationality as a Global Asset, Princeton University Press, Princeton 2019, DOI: https://doi.org/10.23943/princ eton/9780691194066.001.0001.

Jessurun d'Oliveira, H.U., Tjebbes en aanhangend nationaliteit, "Nederlands Juristenblad", no. 37/2019.

Jessurun d'Oliveira, H.U., Union Citizenship and beyond, in: European Citizenship under Stress: Social Fustice, Brexit, and Other Challenges, eds. N. Cambien, D. Kochenov, E. Muir, Brill-Nijhoff, Boston 2020.

Joppke C., Citizenship between De- and Re-Ethnicization, "European Journal of Sociology", no. 429(44)/2003, DOI: https://doi.org/10.1017/ S0003975603001346.

Joppke C. Citizenship and Immigration, Polity, Cambridge 2010.

Joppke C., The Instrumental Turn of Citizenship, "Journal of Ethnic and Migration Studies", no. 858(45)/2019, DOI: https://doi.org/10.1080/13 69183X.2018.1440484. 
Kälin and Kochenov's Quality of Nationality Index, eds. D. Kochenov, J. Lindeboom, Hart Publishing, Oxford 2020, DOI: https://doi. org/10.5040/9781509933242.

Kälin C., Ius Doni in International and European Law, Brill-Nijhoff, Boston 2019, DOI: https://doi.org/10.1163/9789004357525.

Kendall E., Green Cards as the Ultimate Dividends: Why Improving the US Investment Visa Program Will Encourage the Economic Recovery by Increasing Foreign Investment and Creating Fobs for Americans, "Georgetown Immigration Law Journal", no. 580(27)/2013.

Klamert M., The Principle of Loyalty in EU Law, Oxford University Press, Oxford 2014, DOI: https://doi.org/10.1093/acprof:oso/9780199683123. 001.0001 .

Kochenov D., Ius Tractum of Many Faces: European Citizenship and the Difficult Relationship between Status and Rights, "Columbia Journal of European Law", no. 169(15)/2009.

Kochenov D., Rounding up the Circle: The Mutation of Member States Nationalities under Pressure from EU Citizenship, "EUI RSCAS Working Paper", no. 23/2010.

Kochenov D., Mevrouw De fong Gaat Eten: EU Citizenship and the Culture of Prejudice, "EUI RSCAS Working Paper", no. 6/2011.

Kochenov D., Citizenship for Real: Its Hypocrisy, Its Randomness, Its Price, in: Debating Transformations of National Citizenship, ed. R. Bauböck, Springer, Berlin 2018, DOI: https://doi.org/10.1007/978-3-319-92719-0_11.

Kochenov D., Citizenship, MIT Press, Cambridge MA 2019, DOI: https:// doi.org/10.7551/mitpress/11351.001.0001.

Kochenov D., The Oxymoron of "Market Citizenship" and the Future of the European Union, in: The Internal Market and the Future of European Integration: Essays in Honour of Laurence W. Gormley, ed. F. Amtenbrink et al., Cambridge University Press, Cambridge 2019, DOI: https://doi. org/10.1017/9781108565417.016.

Kochenov D., The Tjebbes Fail, "European Papers", no. 319(4)/2019.

Kochenov D., "Passport Trade": The Vicious Circle of Nonesense in the Netherlands', Verfassungsblog, 8 June 2020.

Kochenov D., van den Brink M., Pretending There Is No Union: Non-Derivative Quasi-Citizenship Rights of Third-Country Nationals in the EU, in: Degrees of Free Movement and Citizenship, eds. D. Thym, M. ZoetewijTurhan, Brill/Nijhoff, Leiden 2015, DOI: https://doi.org/10.2139/ssrn.2587661.

Kochenov D., Lindeboom J., Empirical Assessment of the Quality of Nationalities, "European Journal of Law and Governance", no. 314(4)/2017, DOI: https://doi.org/10.1163/22134514-00404007. 
Kochenov D., Lindeboom J., Pluralism Through its Denial, in: Research Handbook on Legal Pluralism and EU Law, eds. G. Davies, M. Avbelj, Edward Elgar, Cheltenham 2018.

Kostakopoulou D., Why Naturalization?, "Perspectives on European Politics and Society", no. 85(3)/2003, DOI: https://doi.org/10.1080/ 15705850308438854.

Lester A., Thirty Years on: The East African Case Revisited, "Public Law", no. 52(47)/2002.

Lindeboom J., Meunier S., Foreign Direct Investment and Investment Migration Programmes in the European Union, in: Citizenship and Residence Sales: Rethinking the Boundaries of Belonging, eds. D. Kochenov, K. Surak, Cambridge University Press, Cambridge 2021 (forthcoming).

Margiotta C., Ricchi e poveri alla prova della cittadinanza europea. Annotazioni sulla Relazione della Commissione europea sui programmi di cittadinanza per investitori, "Ragion Pratica", no. 2/2020.

Maas W., Creating European Citizens, Rowman and Littlefield, Boston 2007.

Milanovic B., Global Inequality, Harvard University Press, Cambridge MA 2018.

O’Brien C., Unity in Adversity, Hart Publishing, Oxford 2017.

Popov V., Why Some Countries Have More Billionaires than Others? Explaining Variety in the Billionaire Intensity of GDP, "Investment Migration Research Papers", no. 3/2018, DOI: https://doi.org/10.2139/ssrn.3189026.

Prak M., Citizens without Nations, Cambridge University Press, Cambridge 2018, DOI: https://doi.org/10.1017/9781316219027.

Reding V., Citizenship Must Not be Up for Sale, European Commission Speech, 14/18/2014.

Roy S., The "Streetlight Effect" in Commentary on Citizenship by Investment, in: Citizenship and Residence Sales: Rethinking the Boundaries of Belonging, eds. D. Kochenov, K. Surak, Cambridge University Press, Cambridge 2021 (forthcoming).

Sarmiento D., EU Competence and the Attribution of Nationality in Member States, "Investment Migration Research Paper", no. 2/2019.

Sarmiento D., van den Brink M., EU Competence and Investor Migration, in: Citizenship and Residence Sales: Rethinking the Boundaries of Belonging, eds. D. Kochenov, K. Surak, Cambridge University Press, Cambridge 2021 (forthcoming).

Shachar A., The Birthright Lottery, Harvard University Press, Cambridge MA 2009, DOI: https://doi.org/10.2307/j.ctvihzr8r.

Shachar A., Dangerous Liasons: Money and Citizenship, in: Transformations of National Citizenship, ed. R. Bauböck, Debating, Springer, Berlin 2018, DOI: https://doi.org/10.1007/978-3-319-92719-0_2. 
Shachar, A., Citizenship for Sale?, in: The Oxford Handbook of Citizenship, ed. A. Shachar et al., Oxford University Press, Oxford 2019.

Shaw J., Citizenship for Sale: Could and Should the EU Intervene?, in: Debating Transformations of National Citizenship, ed. R. Bauböck, Springer, Berlin 2018, DOI: https://doi.org/10.1007/978-3-31992719-0_13.

Solimano A., Global Mobility of the Wealthy and Their Assets: An Overview, "Investment Migration Research Papers", no. 2/2018.

Spiro P., Cash-for-Passports and the End of Citizenship, in: Debating Transformations of National Citizenship, ed. R. Bauböck, Springer, Berlin 2018, DOI: https://doi.org/10.1007/978-3-319-92719-0_3.

Spiro P., Nottebohm and "Genuine Link": The Anatomy of Furisprudential Illusion, "Investment Migration Research Paper", no. 1/2019.

Sumption M., Can Investor Residence and Citizenship Programmes be a Policy Success?, in: Citizenship and Residence Sales: Rethinking the Boundaries of Belonging, eds. D. Kochenov, K. Surak, Cambridge University Press, Cambridge 2021 (forthcoming).

Sumption M., Hooper K., Selling Visas and Citizenship: Policy Questions from the Global Boom in Investor Immigration, Migration Policy Institute, Washington DC 2014.

Surak K., Global Citizenship 2.0 - The Growth of Citizenship by Investment Programmes, "Investment Migration Research Papers", no. 3/2016.

Surak K., Millionaire Mobility and the Sale of Citizenship, "Journal of Ethnic and Migration Studies", no. 47(1) 2021, DOI: https://doi.org/10.1080/1 369183X.2020.1758554.

Surak K., Citizenship 4 Sale, Harvard University Press. Cambridge MA (forthcoming).

Swider K., Legitimising Precarity of EU Citizenship: Tjebbes, "Common Market Law Review", no. 1163(57)/2020.

Tanasoca A., Citizenship for Sale: Neomedieval Not fust Neoliberal, "European Journal of Sociology", no. 169(57)/2016, DOI: https://doi. org/10.1017/S0003975616000059.

Thiele L., Decker S., Residence in the United States through Investment: Reality or Chimera, "Albany Government Law Review", no. 103(3)/2010.

Toner H., Annotation Case C-192/99 Kaur [2001], "Common Market Law Review”, no. 881(37)/2002.

Tratnik M., Weingerl P., Investment Migration and State Autonomy: The Quest for the Relevant Link, "Investment Migration Research Papers", no. 4/2019.

Tryfonidou A., Investment Residence in the UK: Past and Future, "Investment Migration Policy Brief", no. 1/2017. 
Tully J., On Global Citizenship, Bloomsbury Academic, London 2014, DOI: https://doi.org/10.26530/OAPEN_479572.

Van Fossen A., Citizenship for Sale: Passports of Convenience from Pacific Island Tax Havens, "Commonwealth and Comparative Politics", no. 45(138)/2007, DOI: https://doi.org/10.1080/14662040701317477.

Weiler J.H.H., Europe: The Case against the Case of Statehood, "European Law Journal", no. 43(4)/1998, DOI: https://doi.org/10.1111/14680386.00042 .

Weingerl P., Tratnik M., Relevant Links: Investment Migration as an Expression of State Autonomy in Matters of Nationality, in: Citizenship and Residence Sales: Rethinking the Boundaries of Belonging, eds. D. Kochenov, K. Surak, Cambridge University Press, Cambridge 2021 (forthcoming). 